\title{
IMPLEMENTASI KEBIJAKAN PERATURAN WALI KOTA BOGOR NOMOR 61 TAHUN 2018 TENTANG PENGURANGAN PENGGUNAAN KANTONG PLASTIK DI KOTA BOGOR
}

\author{
POLICY IMPLEMENTATION OF BOGOR MAYOR REGULATION \\ NO. 61/2018 REGARDING REDUCTION OF USING PLASTIC BAGS \\ IN BOGOR CITY
}

\author{
Siti Shopiatul Islami*, Irma Purnamasari², G. Goris Seran ${ }^{3}$ \\ 1,2,3Program Studi Administrasi Publik, Fakultas Ilmu Sosial dan Ilmu Politik, Universitas \\ Djuanda, Jl. Tol Ciawi No. 1, Kotak Pos 35, Bogor 16720 \\ *Korespondensi: Siti Shopiatul Islami. Email: sitishopiatul.islami@unida.ac.id
}

(Diterima: 10-02-2020; Ditelaah: 26-02-2020; Disetujui: 10-03-2020)

\begin{abstract}
The aim of this research is to describe the policy implementation of Bogor Mayor Regulation No. 61/2018 regarding Reduction of Using Plastic Bags in Bogor City. This research uses Richard E. Matland's ambiquity-conflict theory of policy implementation including four dimensions, namely policy accuracy, implementer accuracy, target accuracy and enviromental accuracy. Method of this research is descriptivequalitative. The respondents stem from the civil servants of the Environment Arrangement Unit of the Local Agency for Environment of Bogor City and 19 Shopping Centers and Modern Department Stores. The main instrument for collecting data is questionaires, then supported by the interviews, observations and library/documentation/regulation studies. The collected data are analyzed by the formula of Weight Mean Score to calculate the mean score. Results of this research indicate that the policy implementation of reduction of using plastic bags in Bogor City is good. It is based on the application of the program in accordance with the regulation and the decreasing rate of significantly using plastic bags. The policy implementation of the regulation indicates the administrative implementation, having low ambiquity and low conflict among the policy implementer, the policy target and the community as customer. However, this research finds the lowest understanding of community about environment.
\end{abstract}

Key words: Bogor City, Reduction of Using Plastic Bags, Policy Implementation, Shopping Center and Modern Department Store.

\begin{abstract}
ABSTRAK
Tujuan dari penelitian ini adalah untuk mengetahui implementasi kebijakan Peraturan Wali Kota Bogor Nomor 61 Tahun 2018 tentang Pengurangan Penggunaan Kantong Plastik di Kota Bogor. Penelitian ini menggunakan teori ambiguitas-konflik implementasi kebijakan dari Richard E. Matland yang mencakup empat dimensi, yaitu ketepatan kebijakan, ketepatan pelaksana, ketepatan target, dan ketepatan lingkungan. Metode penelitian bersifat deskriptif-kualitatif. Responden penelitian adalah pegawai Bidang Tata Lingkungan Dinas Lingkungan Hidup Kota Bogor dan 19 Pusat Perbelanjaan dan Pertokoan Modern di Kota Bogor. Instrumen utama pengumpulan data adalah kuesioner, yang kemudian dibantu dengan wawancara, pengamatan dan pustaka/dokumentasi. Data yang telah dikumpulkan dianalisis dengan rumus Weight Mean Score untuk mendapatkan skor rerata. Hasil penelitian menunjukkan bahwa implementasi kebijakan pengurangan penggunaan kantong plastik di Kota Bogor adalah baik. Hal ini dapat dilihat dari penerapan program yang berjalan sesuai aturan dan angka penurunan penggunaan kantong plastik yang signifikan. Implementasi kebijakan peraturan ini menunjukkan administrative implementation, dimana terdapat tingkat ambiguitas yang rendah dan tingkat konflik yang rendah di antara pelaksana kebijakan, sasaran kebijakan dan masyarakat pengguna. Namun ditemukan masih sangat rendahnya pemahaman masyarakat mengenai lingkungan.
\end{abstract}

Kata kunci: Kota Bogor, Pengurangan Penggunaan Kantong Plastik, Implementasi Kebijakan, Pusat Perbelanjaan dan Pertokoan Modern.

Islami, Siti Shopiatul, Purnamasari, Irma \& Seran, G. Goris. (2020). Implementasi Kebijakan Peraturan Wali Kota Bogor Nomor 61 Tahun 2018 tentang Pengurangan Penggunaan Kantong Plastik di Kota Bogor. Jurnal GOVERNANSI, 6(1): 1-8. 


\section{PENDAHULUAN}

Lingkungan hidup yang baik dan sehat merupakan hak asasi setiap warga negara Indonesia sebagaimana diamanatkan dalam Undang-Undang Dasar Negara Republik Indonesia Tahun 1945, Pasal 28H ayat (1), bahwa "Setiap orang berhak hidup sejahtera lahir dan batin, bertempat tinggal, dan mendapatkan lingkungan hidup yang baik dan sehat serta berhak memperoleh pelayanan kesehatan." Sejalan dengan amanat konstitusi tersebut, lingkungan hidup yang baik dan sehat menjadi salah satu bagian dari proses pembangunan yang harus pemerintah kota perhatikan, bahwa tingkat lingkungan hidup yang baik dan sehat pada suatu kota dapat berpengaruh secara signifikan pada proses peningkatan kualitas sumber daya manusia secara nasional. Semakin baik dan sehat lingkungan hidup penduduk suatu kota dapat menimbulkan dampak yang baik terhadap tingkat perkembangan kualitas sumber daya manusia penduduk kota tersebut. Hal ini tentu saja sejalan dengan tujuan pembangunan nasional Indonesia untuk menciptakan bangsa yang maju dan mandiri.

Kerusakan dan pencemaran lingkungan hidup telah mengemuka menjadi suatu permasalahan klasik daerah perkotaan. Dan permasalahan ini tentu saja membutuhkan solusi kongkrit sehingga mampu mengurangi tingkat perkembangan kerusakan dan pencemaran lingkungan hidup dimaksud. Lahirnya Undang-Undang Nomor 32 Tahun 2009 tentang Perlindungan dan Pengelolaan Lingkungan Hidup merupakan upaya legal sistematis untuk melestarikan fungsi lingkungan hidup dan mencegah terjadinya pencemaran dan kerusakan ekosistem sumber daya alam dan manusia, dalam hal ini mengatasi terjadinya pencemaran dan kerusakan ekosistem lingkungan karena pencemaran sampah plastik.

Undang-Undang Nomor 23 Tahun 2014 tentang Pemerintahan Daerah, Bagian Ketiga Urusan Pemerintahan Konkuren, Pasal 12 ayat (2) huruf e, mengatur tentang lingkungan hidup sebagai urusan pemerin- tahan wajib yang tidak berkaitan dengan pelayanan dasar, akan tetapi menjadi urusan pemerintahan konkuren yang dibagi bersama pemerintah pusat dan pemerintah daerah. Dengan penguatan hak otonomi daerah melalui desentralisasi urusan pemerintahan tersebut, maka Pemerintah Kota Bogor memiliki kewenangan dalam menyelesaikan permasalahan lingkungan hidup yang disebabkan oleh pencemaran dan kerusakan lingkungan hidup sebagai akibat dari sampah plastik. Terkait lingkungan hidup, Kota Bogor telah menerbitkan dua peraturan daerah, yaitu Peraturan Daerah Kota Bogor Nomor 9 Tahun 2012 tentang Pengelolaan Sampah dan Peraturan Daerah Kota Bogor Nomor 1 Tahun 2014 tentang Perlindungan dan Pengelolaan Lingkungan Hidup. Peraturan-peraturan daerah ini dimaksudkan sebagai upaya legal untuk mengelola sampah dan lingkungan hidup secara baik dan benar guna memberikan perlindungan dan meningkatkan kesehatan masyarakat Kota Bogor.

Upaya untuk meningkatkan kesehatan masyarakat dan kualitas lingkungan hidup di Kota Bogor salah satunya adalah dengan menanggulangi bertambahnya penimbunan sampah khususnya pemakaian sampah plastik yang merupakan sampah dengan dampak pencemaran lingkungan tertinggi. Diketahui bahwa jumlah penumpukan sampah di Kota Bogor berada pada angka 600 ton/hari dimana 13\% dari jumlah penumpukan tersebut berasal dari sampah plastik, terhitung sebanyak 78 ton sampah plastik ditimbun dalam satu hari. Dalam merespons permasalahan tersebut, Pemerintah Kota Bogor telah menerbitkan Peraturan Wali Kota Bogor Nomor 61 Tahun 2018 tentang Pengurangan Penggunaan Kantong Plastik. Adapun sasaran kebijakan dari Peraturan Wali Kota Bogor Nomor 61 Tahun 2018 adalah pusat perbelanjaan dan pertokoan modern.

Berdasarkan latar belakang tersebut, maka sasaran kebijakan dari Peraturan Wali Kota Bogor Nomor 61 Tahun 2018 yang menjadi sasaran penelitian ini adalah 24 
pusat perbelanjaan dan pertokoan modern di Kota Bogor yang selanjutnya dispesifikasi menjadi gerai besar dan kecil sesuai dengan jumlah penggunaan kantong plastik yang dibutuhkan dalam rentang waktu satu bulan. Hal ini mendorong peneliti untuk meneliti lebih mendalam mengenai implementasi kebijakan Peraturan Wali Kota Bogor Nomor 61 Tahun 2018 tentang Pengurangan Penggunaan Kantong Plastik di Kota Bogor.

\section{MATERI DAN METODE}

\section{Konsep/Teori yang Relevan}

Penelitian tentang implementasi kebijakan ini menggunakan teori implementasi kebijakan dari Richard E. Matland (1995). Richard E. Matland (1995) mengembangkan matriks dan model ambiguitas-konflik implementasi kebijakan (Yulianto Kadji, 2015) sebagai berikut:

(a) Administrative Implementation: Low Policy Ambiguity and Low Policy Conflict. Implementasi secara administratif adalah implementasi yang dilakukan dalam keseharian operasi birokrasi pemerintah. Kebijakan di sini memiliki ambiguitas atau kemenduaan yang rendah dan konflik yang rendah.

(b) Political Implementation: Low Policy Ambiguity and High Policy Conflict. Implementasi secara politik adalah implementasi yang perlu dipaksakan secara politik, karena walaupun ambiguitasnya rendah akan tetapi tingkat konfliknya tinggi.

(c) Experimental Implementation: High Policy Ambiguity and Low Policy Conflict. Implementasi secara eksperimental dilakukan pada kebijakan yang mendua namun tingkat konfliknya rendah. Implementasi secara eksperimental dilakukan pada kebijakan yang mempunyai ambiguitas tinggi dan konflik rendah.

(d) Symbolic Implementation: High Policy Ambiguity and High Policy Conflict. Implementasi secara simbolik dilakukan pada kebijakan yang mempunyai ambi- guitas yang tinggi dan konflik yang tinggi. Kebijakan di sini mempunyai ambiguitas dan konflik yang sama-sama tinggi.

Matriks dan model ambiguitas-konflik implementasi kebijakan dari Richard E. Matland (1995) digambarkan secara lebih jelas dan rinci sebagai berikut:

Tabel 1. Matriks Ambiguitas-Konflik Matland

\begin{tabular}{lll}
\hline $\begin{array}{l}\text { High } \\
\text { Ambi- } \\
\text { guity }\end{array}$ & $\begin{array}{l}\text { Experimental } \\
\text { implementation }\end{array}$ & $\begin{array}{l}\text { Symbolic } \\
\text { implementation }\end{array}$ \\
\cline { 2 - 3 } & $\begin{array}{l}\text { Implementation } \\
\text { decided by contextual } \\
\text { conditions }\end{array}$ & $\begin{array}{l}\text { Implementation } \\
\text { decided by coalition } \\
\text { strength }\end{array}$ \\
\cline { 2 - 3 } & Example: headstart & $\begin{array}{l}\text { Example: community } \\
\text { action agencies }\end{array}$ \\
\hline $\begin{array}{l}\text { Low } \\
\text { Ambi- } \\
\text { guity }\end{array}$ & $\begin{array}{l}\text { Administrative } \\
\text { implementation }\end{array}$ & $\begin{array}{l}\text { Political } \\
\text { implementation }\end{array}$ \\
\cline { 2 - 3 } & $\begin{array}{l}\text { Implementation } \\
\text { decided by recources }\end{array}$ & $\begin{array}{l}\text { Implementation } \\
\text { decided by power }\end{array}$ \\
\cline { 2 - 3 } & $\begin{array}{l}\text { Example: smallpox } \\
\text { eradication }\end{array}$ & Example: busing \\
\hline & Low Conflict & High Conflict \\
\hline
\end{tabular}

Sumber: Richard E. Matland (Dian Purwanti, 2019)

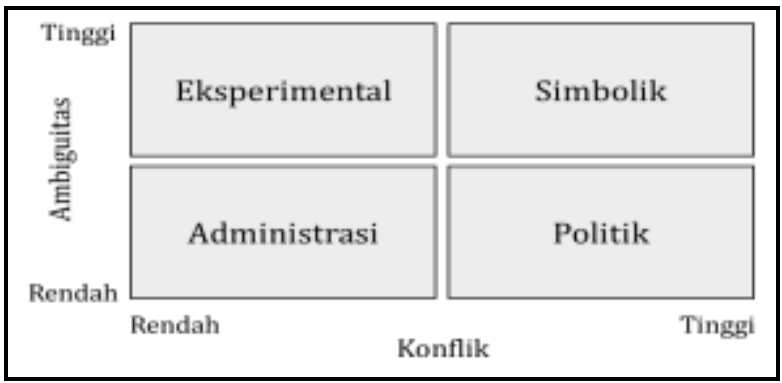

Sumber: Richard E. Matland (Dian Purwanti, 2019)

Gambar 1. Model Ambiguitas-Konflik Matland

Pendekatan Richard E. Matland (1995) memiliki empat tepat yang perlu dipenuhi dalam hal keefektifan implementasi kebijakan, yaitu (1) ketepatan kebijakan, (2) ketepatan pelaksanaan, (3) ketepatan target, dan (4) ketepatan lingkungan. Keempat "tepat" tersebut masih perlu didukung dengan ketiga jenis dukungan, yaitu (a) dukungan politik, (b) dukungan strategis, dan (c) dukungan teknis. Selain ketiga dukungan tersebut, penelitian ataupun analisis tentang implementasi kebijkan sebaiknya juga menggunakan model implementasi sesuai dengan isu kebijakan, sebagaimana yang digambarkan oleh Richard E. Matland (Dian Purwanti, 2019). 


\section{Metode}

Metode yang digunakan dalam penelitian ini adalah metode deskriptif, yaitu metode yang dipakai untuk mengetahui nilai variabel mandiri (Sugiyono, 2014). Penelitian ini hendak menggambarkan implementasi kebijakan Peraturan Wali Kota Bogor Nomor 61 Tahun 2018 tentang Pengurangan Penggunaan Kantong Plastik di Kota Bogor. Responden penelitian dibagi ke dalam dua kelompok sasaran, yaitu pegawai Bidang Tata Lingkungan Dinas Lingkungan Hidup Kota Bogor dan Pusat Perbelanjaan dan Pertokoan Modern di Kota Bogor.

Teknik pengumpulan data dalam penelitian ini adalah sebagai berikut:

1) Kuesioner. Teknik utama pengumpulan data penelitian ini adalah kuesioner/ angket. Peneliti mengumpulkan data dengan cara memberikan serangkaian pertanyaan tertulis kepada responden untuk dijawab. Peneliti membagikan kuesioner/angket kepada dua kelompok sasaran responden, yaitu pegawai Bidang Tata Lingkungan Dinas Lingkungan Hidup Kota Bogor dan 19 Pusat Perbelanjaan dan Pertokoan Modern di Kota Bogor.

2) Wawancara. Teknik pengumpulan data dilakukan dengan cara tanya-jawab kepada responden secara lisan tentang implementasi kebijakan Peraturan Walikota Bogor Nomor 61 Tahun 2018 tentang Pengurangan Penggunaan Kantong Plastik di Kota Bogor.

3) Observasi. Teknik pengumpulan data dilakukan dengan cara pengamatan langsung di lokasi penelitian, yaitu Dinas Lingkungan Hidup Kota Bogor serta Pusat Perbelanjaan dan Pertokoan Modern di Kota Bogor, terkait implementasi kebijakan tersebut.

4) Studi Kepustakaan (Library Research). Teknik penelitian ini memperoleh data sekunder yang bersumber dari kepustakaan, dokumen dan peraturan perundang-undangan terkait implementasi kebijakan tersebut.
Analisis data penelitian dilakukan secara kualitatif dengan mengelompokkan data berdasarkan dimensi dan jenis jawaban responden, mentabulasi data dan melakukan penghitungan guna menjawab masalah penelitian. Kuesioner/angket penelitian menggunakan skala Likert, yang terbagi ke dalam 5 pilihan jawaban dan disusun secara ordinal, mulai dari sangat setuju dengan skor 5 , setuju dengan skor 4 , cukup dengan 3 , tidak setuju dengan skor 2 , dan sangat tidak setuju dengan skor 1 . Penghitungan menggunakan Rumus Weight Mean Score (WMS) untuk mendapatkan skor rerata (mean/M) terhadap jawaban responden penelitian. Berdasarkan skor rerata tersebut kemudian diinterpretasi kategori implementasi kebijakan.

\section{HASIL DAN PEMBAHASAN}

Variabel implementasi kebijakan yang terdapat pada Peraturan Wali Kota Bogor Nomor 61 Tahun 2018 tentang Pengurangan Penggunaan Kantong Plastik di Kota Bogor diukur berdasarkan empat dimensi, yaitu ketepatan kebijakan, ketepatan pelaksana, ketepatan target, dan ketepatan lingkungan. Adapun hasil penelitian tentang implementasi kebijakan yang diukur berdasarkan keseluruhan dimensi tersebut ditunjukkan pada Tabel 2.

Tabel 2. Rekapitulasi Skor Keseluruhan Dimensi Implementasi Kebijakan

Pegawai Bidang Tata Lingkungan:

\begin{tabular}{llcc}
\hline No. & Dimensi & Rerata & Kategori \\
\hline 1. & Ketepatan Kebijakan & 4,13 & Baik \\
\hline 2. & Ketepatan Pelaksana & 4,02 & Baik \\
\hline 3. & Ketepatan Target & 4,10 & Baik \\
\hline 4. & Ketepatan Lingkungan & 4,16 & Baik \\
\hline & Jumlah & 4,10 & Baik \\
\hline
\end{tabular}

Sumber: Kuesioner Penelitian 2020

Pusat Perbelanjaan dan Pertokoan Modern:

\begin{tabular}{llcc}
\hline No. & Dimensi & Rerata & Kategori \\
\hline 1. & Ketepatan Kebijakan & 4,32 & Baik \\
\hline 2. & Ketepatan Pelaksana & 3,82 & Baik \\
\hline 3. & Ketepatan Target & 4,22 & Baik \\
\hline 4. & Ketepatan Lingkungan & 3,73 & Baik \\
\hline & Jumlah & 4,02 & Baik \\
\hline
\end{tabular}

Sumber: Kuesioner Penelitian 2020 
Tabel 2 tersebut di atas menunjukkan rekapitulasi nilai keseluruhan dimensi implementasi Program Bogor Tanpa Kantong Plastik (BOTAK) di Pusat Perbelanjaan dan Pertokoan Modern di Kota Bogor sebagai berikut:

1) Rekapitulasi keseluruhan rerata dimensi skor akhir pada jawaban responden pegawai Bidang Tata Lingkungan Dinas Lingkungan Hidup Kota Bogor sebesar 4,10 yang berada pada kriteria penafsiran kategori baik.

2) Rekapitulasi keseluruhan rerata dimensi pada Pusat Perbelanjaan dan Pertokoan Modern di Kota Bogor menunjukan skor 4,02 yang berada pada kriteria penafsiran baik.

Dengan hasil rekapitulasi kategori baik tersebut, maka setiap dimensi memiliki deskripsi hasil tersebut sebagai berikut:

(1) Ketepatan Kebijakan didukung berdasarkan bukti angka penurunan penggunaan sampah plastik pada 24 Pusat Perbelanjaan dan Pertokoan Modern di Kota Bogor selama periode waktu 1 tahun terhitung sejak bulan Juli 2018 hingga Juni 2019 selama program berjalan sebesar 164.000 kilogram atau 164 ton sampah plastik berkurang, dengan jumlah hitung angka per 3 bulan penurunan sebesar 43 ton.

(2) Ketepatan Pelaksana didukung berdasarkan kecakapan proses pelaksanaan program pengurangan penggunaan kantong plastik. Pemerintah Kota Bogor selaku implementor kebijakan mampu bekerja sama dengan Pusat Perbelanjaan dan Pertokoan Modern di Kota Bogor selaku sasaran kebijakan dalam menjalankan kebijakan Peraturan Wali Kota Bogor Nomor 61 Tahun 2018 tentang Pengurangan Penggunaan Kantong Plastik di Kota Bogor.

(3) Ketepatan Target didukung berdasarkan bukti kecakapan proses pelaksanaan program pengurangan penggunaan kantong plastik. Hal ini ditandai dengan pakta integritas bahwa dengan lahirnya Peraturan Wali Kota Bogor Nomor 61 Tahun 2018 tentang Pengurangan Penggunaan Kantong Plastik di Kota Bogor dapat diterima dengan baik oleh masyarakat.

(4) Ketepatan Lingkungan didukung berdasarkan bukti penilaian hasil pada pada dimensi ketepatan lingkungan.

Keefektifan implementasi kebijakan Peraturan Wali Kota Bogor Nomor 61 Tahun 2018 tentang Pengurangan Penggunaan Kantong Plastik di Kota Bogor telah terlaksana dengan baik. Hal ini dibuktikan dengan pola penurunan sampah plastik pada dimensi ketepatan kebijakan, proses sosialisasi yang berjalan baik, konektivitas dan koordinasi antar instansi daerah berjalan baik, serta penerimaan masyarakat selaku pengguna kantong plastik dapat diterima baik. Di lapangan, kendala yang masih dihadapi dalam implementasi kebijakan Peraturan Wali Kota Bogor Nomor 61 Tahun 2018 tentang Pengurangan Penggunaan Kantong di Kota Bogor meliputi masih sangat rendahnya pemahaman masyarakat mengenai lingkungan.

Ketepatan implementasi kebijakan Peraturan Wali Kota Bogor Nomor 61 Tahun 2018 tentang Pengurangan Penggunaan Kantong Plastik di Kota Bogor telah didukung oleh tiga jenis dukungan sebagai berikut:

(1) Dukungan Politik berhubungan dengan adanya peraturan yang melandasi implementasi kebijakan pengurangan penggunaan kantong plastik di Kota Bogor berupa Peraturan Wali Kota Bogor Nomor 61 Tahun 2018 dan dukungan masyarakat terhadap pelaksanaan kebijakan, yaitu dengan mengikuti proses sosialisasi dan penyuluhan serta menjalankannya.

(2) Dukungan Strategis berupa dukungan yang diberikan sasaran kebijakan, yaitu Pusat Perbelanjaan dan Pertokoan Modern di Kota Bogor dalam hal penyediaan tempat yang dapat dipergunakan oleh Pemerintah Kota Bogor dalam melaksanakan sosialisasi dan penyuluhan tentang kebijakan peraturan yang diberlakukan oleh Pemerintah Kota Bogor. 
(3) Dukungan Teknis berupa dukungan yang diberikan oleh Pemerintah Kota Bogor, dalam hal ini Dinas Lingkungan Hidup, kepada sasaran kebijakan dan masyarakat perihal jenis kebijakan peraturan yang diberlakukan oleh Pemerintah Kota Bogor dalam bentuk sosialisasi dan penyuluhan secara berkala tentang pengurangan penggunaan kantong plastik di Kota Bogor sebagaimana diatur dalam Peraturan Wali Kota Bogor Nomor 61 Tahun 2018.

Dengan demikian, pembahasan implementasi kebijakan Peraturan Wali Kota Bogor Nomor 61 Tahun 2018 tentang Pengurangan Penggunaan Kantong Plastik di Kota Bogor berdasarkan dimensi keefektifan/ketepatan kebijakan dan dukungan kebijakan sebagaimana dikemukakan oleh Richard E. Matland (1995) menunjukkan administrative implementation, karena implementasi kebijakan Peraturan Wali Kota Bogor Nomor 61 Tahun 2018 tentang Pengurangan Penggunaan Kantong Plastik di Kota Bogor memiliki tingkat ambiguitas yang rendah dan tingkat konflik yang rendah di antara pelaksana kebijakan (Pemerintah Kota Bogor, dalam hal ini Dinas Lingkungan Hidup), sasaran kebijakan (Pusat Perbelanjaan dan Pertokoan Modern di Kota Bogor), dan masyarakat.

Dilihat dari sisi policy conflict, hasil penelitian implementasi kebijakan Peraturan Wali Kota Bogor Nomor 61 Tahun 2018 tentang Pengurangan Penggunaan Kantong Plastik di Kota Bogor menemukan tidakterjadinya konflik antara Dinas Lingkungan Hidup sebagai pelaksana kebijakan dengan Pusat Perbelanjaan dan Pertokoan Modern sebagai sasaran kebijakan dan masyarakat sebagai pengguna. Hal ini disebabkan oleh karena hasil implementasi kebijakan tersebut ternyata memberikan dampak positif, yaitu secara efektif mengurangi penumpukan sampah plastik di Kota Bogor. Adapun potensi policy ambiguity dapat saja timbul antara Dinas Lingkungan Hidup, Pusat Perbelanjaan dan Pertokoan Modern, serta masyarakat dalam implementasi kebijakan peraturan tersebut, namun hal ini tidak terjadi karena Dinas Lingkungan Hidup dan Pusat Perbelanjaan dan Pertokoan Modern serta masyarakat sama-sama memahami tujuan dan manfaat dari implementasi kebijakan peraturan. Dalam hal ini sangat rendah policy ambiguity implementasi kebijakan Peraturan Wali Kota Bogor Nomor 61 Tahun 2018.

\section{KESIMPULAN DAN REKOMENDASI}

\section{Kesimpulan}

Berdasarkan uraian hasil penelitian dan pembahasan yang telah dilakukan, maka peneliti dapat menarik kesimpulan sebagai berikut:

Pertama: Rekapitulasi keseluruhan rerata dimensi skor akhir pada jawaban responden pegawai Bidang Tata Lingkungan Dinas Lingkungan Hidup Kota Bogor sebesar 4,10 yang berada pada kriteria penafsiran kategori baik dan rekapitulasi keseluruhan rerata dimensi pada Pusat Perbelanjaan dan Pertokoan Modern di Kota Bogor menunjukkan skor 4,02 yang berada pada kriteria penafsiran kategori baik. Berdasarkan hasil tersebut, maka dimensi ketepatan kebijakan, ketepatan pelaksana, ketepatan target dan ketepatan lingkungan mampu mencapai hasil skor baik. Hal ini menunjukkan bahwa ketepatan/keefektifan implementasi kebijakan Peraturan Wali Kota Bogor Nomor 61 Tahun 2018 tentang Pengurangan Penggunaan Kantong Plastik di Kota Bogor telah terlaksana dengan baik.

Kedua: Ketepatan/keefektifan implementasi kebijakan peraturan tersebut telah didukung oleh: (1) Dukungan Politik terkait adanya peraturan yang melandasi implementasi kebijakan pengurangan penggunaan kantong plastik di Kota Bogor berupa Peraturan Wali Kota Bogor Nomor 61 Tahun 2018 dan dukungan masyarakat terhadap pelaksanaan kebijakan, yaitu dengan mengikuti proses sosialisasi dan penyuluhan serta menjalankannya. (2) Dukungan Strategis berupa dukungan yang diberikan sasaran kebijakan, yaitu Pusat 
Perbelanjaan dan Pertokoan Modern di Kota Bogor dalam hal penyediaan tempat yang dapat dipergunakan oleh Pemerintah Kota Bogor dalam melaksanakan sosialisasi dan penyuluhan tentang kebijakan peraturan yang diberlakukan oleh Pemerintah Kota Bogor. (3) Dukungan Teknis berupa dukungan yang diberikan oleh Pemerintah Kota Bogor, dalam hal ini Dinas Lingkungan Hidup, kepada sasaran kebijakan dan masyarakat perihal jenis kebijakan peraturan yang diberlakukan oleh Pemerintah Kota Bogor dalam bentuk sosialisasi dan penyuluhan secara berkala.

Ketiga: Pembahasan implementasi kebijakan Peraturan Wali Kota Bogor Nomor 61 Tahun 2018 tentang Pengurangan Penggunaan Kantong di Kota Bogor berdasarkan dimensi keefektifan/ketepatan kebijakan dan dukungan kebijakan menunjukkan administrative implementation, karena implementasi kebijakan Peraturan Wali Kota Bogor Nomor 61 Tahun 2018 tentang Pengurangan Penggunaan Kantong Plastik di Kota Bogor memiliki tingkat ambiguitas yang rendah dan tingkat konflik yang rendah di antara pelaksana kebijakan, sasaran kebijakan dan masyarakat pengguna.

\section{Rekomendasi}

Penelitian diharapkan dapat memberikan tambahan pengetahuan berkaitan dengan implementasi kebijakan Peraturan Wali Kota Bogor Nomor 61 Tahun 2018 tentang Pengurangan Penggunaan Kantong Plastik di Kota Bogor. Kebijakan pengurangan penggunaan kantong plastik tersebut dilakukan untuk menjaga dan memperbaiki lingkungan hidup di Kota Bogor. Sehubungan dengan hal tersebut, maka proses yang dilakukan harus tepat sasaran yaitu dengan meningkatnya angka penurunan penggunaan sampah plastik di Kota Bogor.

Di samping itu, hasil penelitian ini diharapkan dapat bermanfaat sebagai bahan masukan untuk pertimbangan dan sumbangan pemikiran yang bermanfaat terkait implementasi kebijakan Peraturan
Wali Kota Bogor Nomor 61 Tahun 2018 tentang Pengurangan Penggunaan Kantong Plastik di Kota Bogor.

\section{DAFTAR PUSTAKA}

\section{Buku}

Adon, Jamaludin Nasrullah. (2017). Sosiologi Perkotaan, Memahami Masyarakat Kota dan Problematikanya. Bandung: CV Pustaka Setia.

Herrabudin. (2016). Studi Kebijakan: Dari Filosofi ke Implementasi. Bandung: CV Pustaka Setia.

Kadji, Yulianto. (2015). Formulasi dan Implementasi Kebijakan Publik, Kepemimpinan dan Perilaku Birokrasi dalam Fakta Realitas. Gorontalo: UNG Press.

Subarsono. (2015). Analisis Kebijakan Publik: Konsep, Teori dan Aplikasi. Yogyakarta: Pustaka Pelajar.

Sugiyono. (2014). Metode Penelitian Kuantitatif Kualitatif dan R\&D. Bandung: Alfabeta.

Suharto, Edi. (2003). Analisis Kebijakan Publik: Panduan Praktis Mengkaji Masalah dan Kebijakan Sosial. Bandung: Alfabeta.

Solichin, Abdul Wahab. (2004). Analisis Kebijakan: Dari Formulasi ke Implementasi Kebijakan Negara. Jakarta: Bumi Aksara.

Usman, Nurdin. (2004). Konteks Implementasi Berbasis Kurikulum. Jakarta: PT. RajaGrafindo Persada.

\section{Jurnal}

Colon, T. and Smolen, M. J. (1996). "Epidomiological Analysis of Persistent Organochlorines Contamination in Ctraceans". Review of Enviroment Contamination and Toxicology, 146: 91-172.

Gustafson. C. G. (1970). “PCB's Prevalent and Persistents". Environment Science and Tecnology, 4: 814-819. 
Lesmana, Wira; Rahmawati, Rita dan Seran, G. Goris. (2017). "Implementasi Peraturan Daerah Kabupaten Bogor Nomor 11 Tahun 2012 Dalam Penataan Minimarket". Jurnal GOVERNANSI, 3(1): 1-12.

Purwanti, Dian; Irawati, Ira; Adiwisastra, Jossy dan Bekti, Herijanto. (2019). "Implementasi Kebijakan Penerimaan Peserta Didik Baru Berdasarkan Sistem Zonasi Di Kota Bandung". Jurnal GOVERNASI, 5(1): 12-23.

Setiawan, Eko; Saleh, Choirul dan Hayat, Ainul. (2012). "Implementasi Kebijakan Bantuan Pendidikan (Studi Tentang Kebijakan Bantuan Pendidikan Masyarakat Kota Dalam Peraturan Wali Kota Surakarta Nomor 11A Tahun 2012)". Jurnal Administrasi Publik (JAP), 2(1): 122-128.

\section{Peraturan Perundang-undangan}

Peraturan Daerah Kota Bogor Nomor 9 Tahun 2012 tentang Pengelolaan Sampah (Lembaran Daerah Kota Bogor Tahun 2012 Nomor 3, Tambahan Lembaran Daerah Kota Bogor Nomor 51).

Peraturan Daerah Kota Bogor Nomor 1 Tahun 2014 tentang Perlindungan dan Pengelolaan Lingkungan Hidup (Lembaran Daerah Kota Bogor Tahun 2014 Nomor 1, Tambahan Lembaran Daerah Kota Bogor Nomor 59).

Peraturan Wali Kota Bogor Nomor 61 Tahun 2018 tentang Pengurangan Penggunaan Kantong Plastik (Berita Daerah Kota Bogor Tahun 2018 Nomor 43).

Undang-Undang Nomor 32 Tahun 2009 tentang Perlindungan dan Pengelolaan Lingkungan Hidup (Lembaran Negara Republik Indonesia Tahun 2009 Nomor 140, Tambahan Lembaran Negara Republik Indonesia Nomor 5059).

Undang-Undang Nomor 23 Tahun 2014 tentang Pemerintahan Daerah (Lem- baran Negara Republik Indonesia Tahun 2014 Nomor 244, Tambahan Lembaran Negara Republik Indonesia Nomor 5587). 